\title{
The importance of SEM-EDS analysis in the study of old mortars
}

\author{
P. Adriano ${ }^{*}$, A. Santos Silva ${ }^{*}$, M.R. Veiga ${ }^{* *}$, J. Mirão $^{* * *}$ and A.E Candeias ${ }^{* * * *}$ \\ *Materials Department, National Laboratory of Civil Engineering, Av. Brasil 101, 1700-066 \\ Lisbon, Portugal,padriano@lnec.pt,ssilva@lnec.pt \\ *** Buildings Department, National Laboratory of Civil Engineering, Av. Brasil 101, 1700-066 \\ Lisbon, Portugal, rveiga@lnec.pt \\ ${ }^{* * *}$ Geosciences Department and Geophysic Center of Évora, University of Évora, R. Romão \\ Ramalho 59, 7000-671 Évora,jmirao@uevora.pt \\ **** Chemistry Department and Chemistry Center of Évora, University of Évora, R. Romão \\ Ramalho 59, 7000-671 Évora, candeias@uevora.pt
}

The study of old mortars composition, using physical-chemical, mineralogical and microstructural characterization has an important role in the preservation of architectural heritage, allowing a deep knowledge about the materials used, construction techniques, possible repairs and degradation processes [1-4].

In this paper, we present representative results of the application of scanning electron microscopy (SEM) coupled with energy dispersive X-ray spectrometry (EDS) analysis in the characterisation of ancient mortars from several historical buildings which illustrate the importance of the technique in complementing and corroborating information from other physical and chemical techniques normally used in the determination of their composition and state of conservation, namely, X-ray diffraction, thermogravimetric and differential thermal analysis, atomic absorption spectroscopy and optical microscopy.

The observations were performed in a JEOL JSM-6400 microscope in freshly fractured surfaces and thin sections after carbon sputtering and complemented with the EDS by a Oxford EDS detector, Inca X-Sight model.

The studied monuments were the Mertola's River Tower ( $6^{\text {th }}$ century), Mertola's Mosque/Church (12th century), Santa Maria Church of Evora (Evora's Cathedral, 12th-16th century) and Elvas Cathedral (16th-18th century), all important classified monuments from Alentejo region, in Southern Portugal, which are being studied in a joint collaboration between the National Laboratory of Civil Engineering and the University of Evora aiming the development of integrated conservation methodologies and the rehabilitation of the important architectural heritage of the South of Portugal.

In order to study ancient mortars it is necessary to collect small samples. This operation is always performed under supervision of conservators and technicians from the Portuguese Institute of Architectural Heritage (IPPAR).

The high resolution of SEM enables one to access the microstructural and morphological properties of the mortars and mortars constituents and additives as well as degradation products.

Old mortars are normally composed of calcitic/dolomitic binders which have typical morphologies composed of small carbonate microcrystallites partially jellified (see fig.1). In some cases, other binders can also be found like in the Mihrab of Mertola's Mosque where gypsum was used instead. EDS elemental analysis can give further information about of the binder composition thus enabling the distinction between aerial or hydraulic binders or, within aerial binders from calcitic and dolomitic nature. 
One important information when dealing with old mortars is the nature of the aggregates, not only in terms of their mineralogical composition but also on their morphology because it can give us strong evidence about the most probable source of the aggregates (sands) used. Fig. 2 shows different types of aggregates found in the mortars from the studied monuments. These results in combination with results from XRD and optical microscopy have proved that the aggregates used in all cases have compositions which can be related to the geological context from the vicinity of the monuments thus proving that the sands used were always from local sources. Moreover, the morphology may indicate that either the aggregates were obtained from local quarries when the particles have sharp edges or that river sediments were used when they exhibit rounded morphology. In some cases, like in Evora's Cathedral and Mertola's River tower, the identification of specific minor mineral phases by optical microscopy and SEM-EDS enabled the determination of the aggregates source, the Sao Bento quarry and the river Guadiana in the vicinity of Evora and Mertola, respectively.

In terms of mortars characterisation methodologies, SEM plays one essential role in the identification of degradation/alteration compounds, biological microorganisms and additives which cannot be assessed by other bulk characterisation techniques. Fig. 3a-d show different types of salts found in some of the mortars. The presence of salts is normally indicative of water diffusion and permeation in the lime matrix which may lead to efflorescence's and cryptoefflorescence's in the renders and in some cases to further degradation pathologies, like scaling and flaking. Another important observation is the presence of calcium silicate crystals in mortars (see fig. 3e,f). These are found in roman mortars and in mortars form later periods $\left(17-19^{\text {th }}\right.$ centuries) formed when pozzolans (natural or artificial) are added to improve the mechanical and hydraulic properties of the mortars and represent technical improvements in the formulation of aerial lime mortars.

Finally, the high resolution of SEM enables the verification of the presence of different types pf microorganisms (see fig. 4) like bacteria, fungus and mould and their distribution and abundance may be indicative of water related degradation and biodegradation phenomena.

In this work the SEM-EDS analysis proved to be an important tool in the characterization of the historical mortars allowing the identification of the type of binder and giving a further insight on the mortars history, technology and degradation processes.

Acknowledgments

The authors wish to acknowledge the Fundacao para a Ciencia e Tecnologia and FEDER for financial support under project POCI/HEC/57915/2004

\section{References}

[1] A.S. Silva, M. Paiva, J. Ricardo, M. Salta, A.M. Monteiro \& A.E. Candeias, Materials Science Forum, 2005, 516, 1643-1647.

[2] A.S. Silva, J. Ricardo, M. Salta, P. Adriano, J. Mirão \& A.E. Candeias, Heritage, Weathering and Conservation, Taylor \& Francis, Madrid, 2006, 85-90.

[3] A.E. Candeias, P. Nogueira, J. Mirão, A. Santos Silva, R. Veiga, M. Gil Casal, I. Ribeiro, A.I. Seruya, in Proceedings of CERC3 Workshop on Chemistry in the Conservation of Cultural Heritage, EU-ARTECH, 4pp, 2006. (http://www.eu-artech.org/files/Ext_ab/candeias.pdf). [4] P. Adriano, A. Santos Silva, R. Veiga, A. Candeias, J. Mirão, in: Proceedings of the 11th Euroseminar on Microscopy Applied to Building Materials, Porto University, Oporto, 2007, 14pp. 

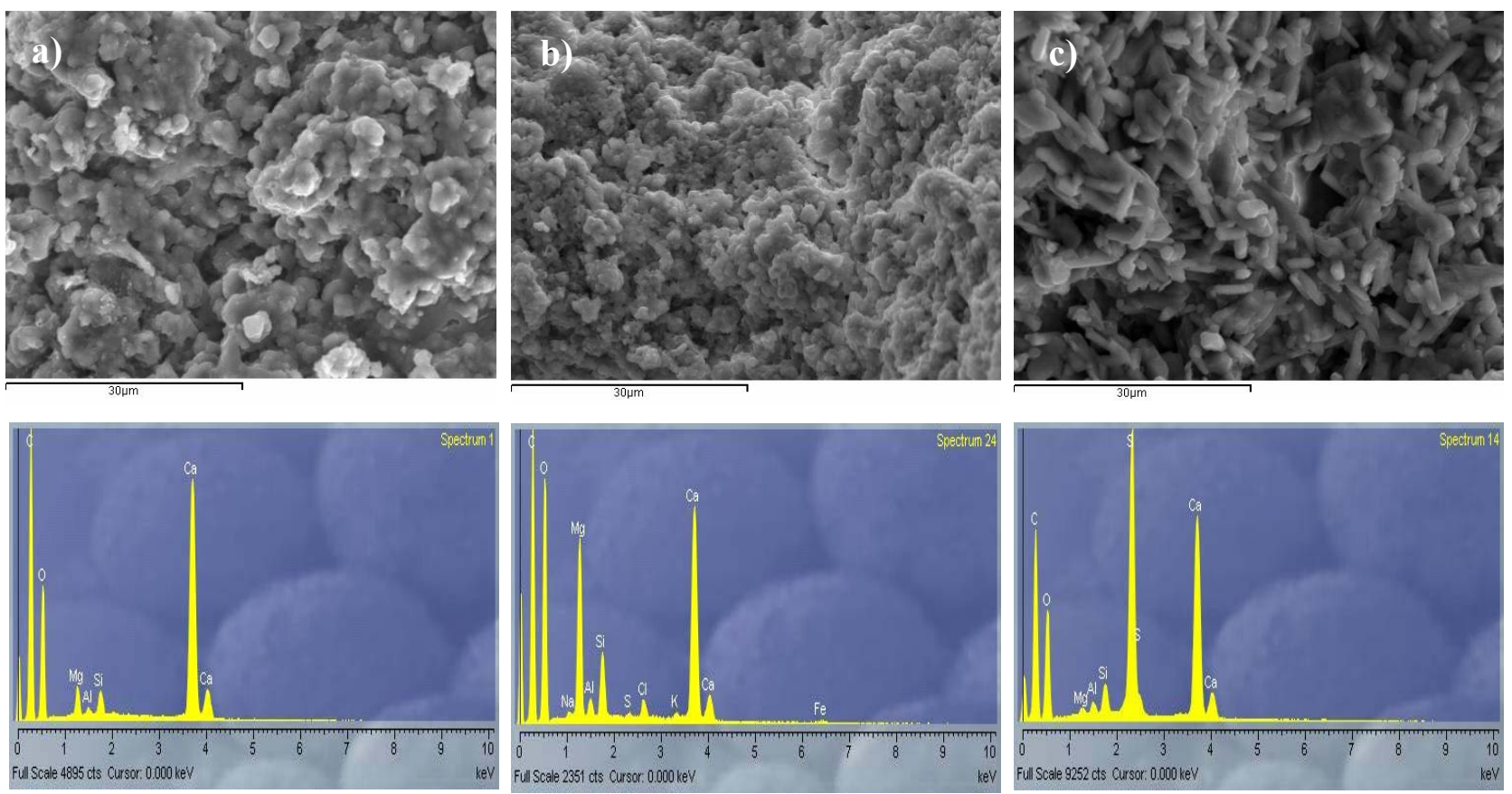

Figure 1. SEM micrographs and EDS spectra of a) calcitic lime matrix mortar (Evora Cathedral) b) dolomitic lime matrix mortar (Evora Cathedral) c) gypsum matrix mortar (Mertola Mosque).
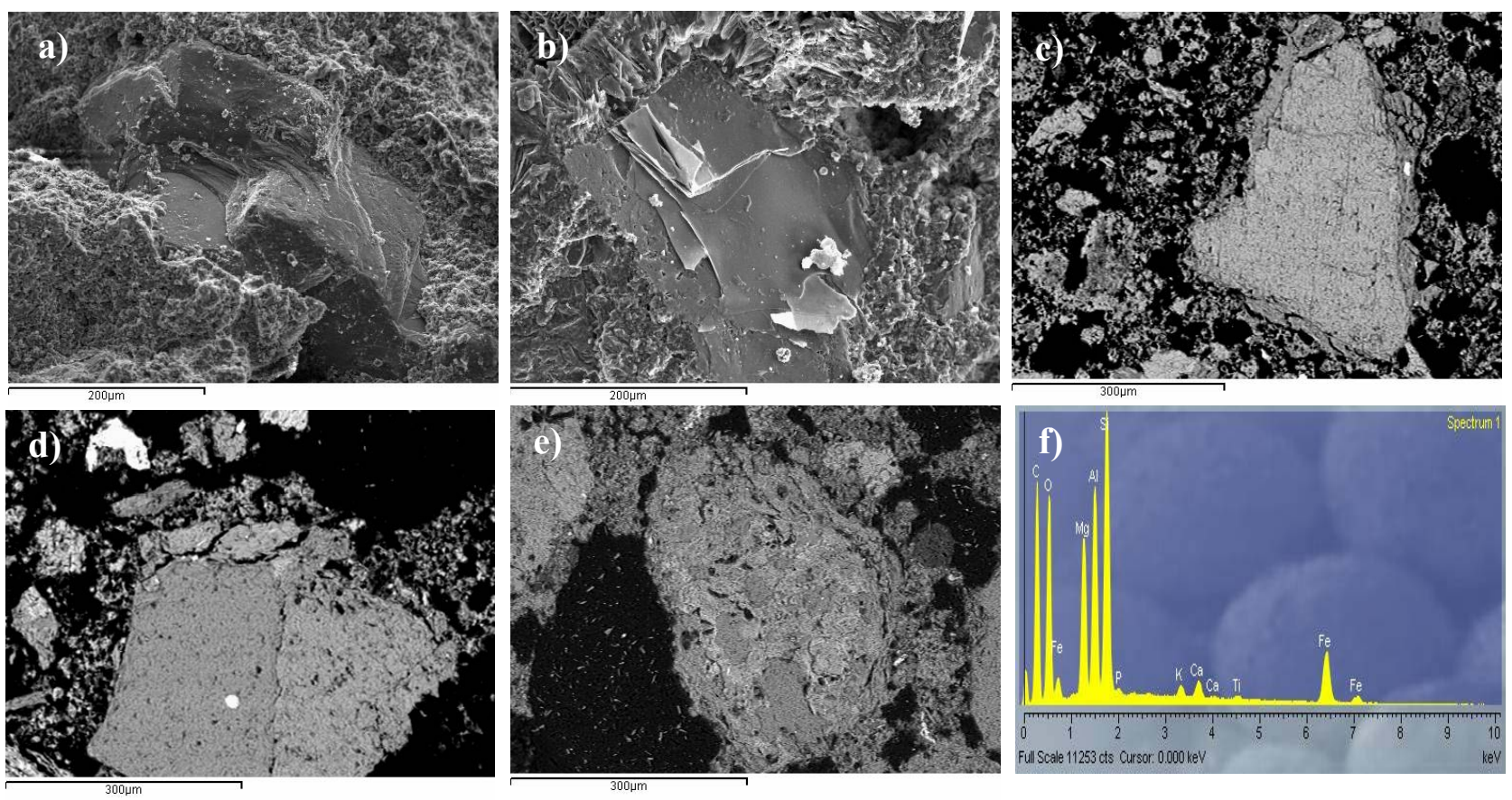

Figure 2. SEM micrographs of aggregates: a) Quartz grain (Evora Cathedral); b) altered mica (Evora Cathedral); c) plagioclases (Elvas Cathedral - thin section) d) feldspar (Elvas Cathedral thin section) e) ceramic fragment (Elvas Cathedral) and f) corresponding EDS spectrum. 

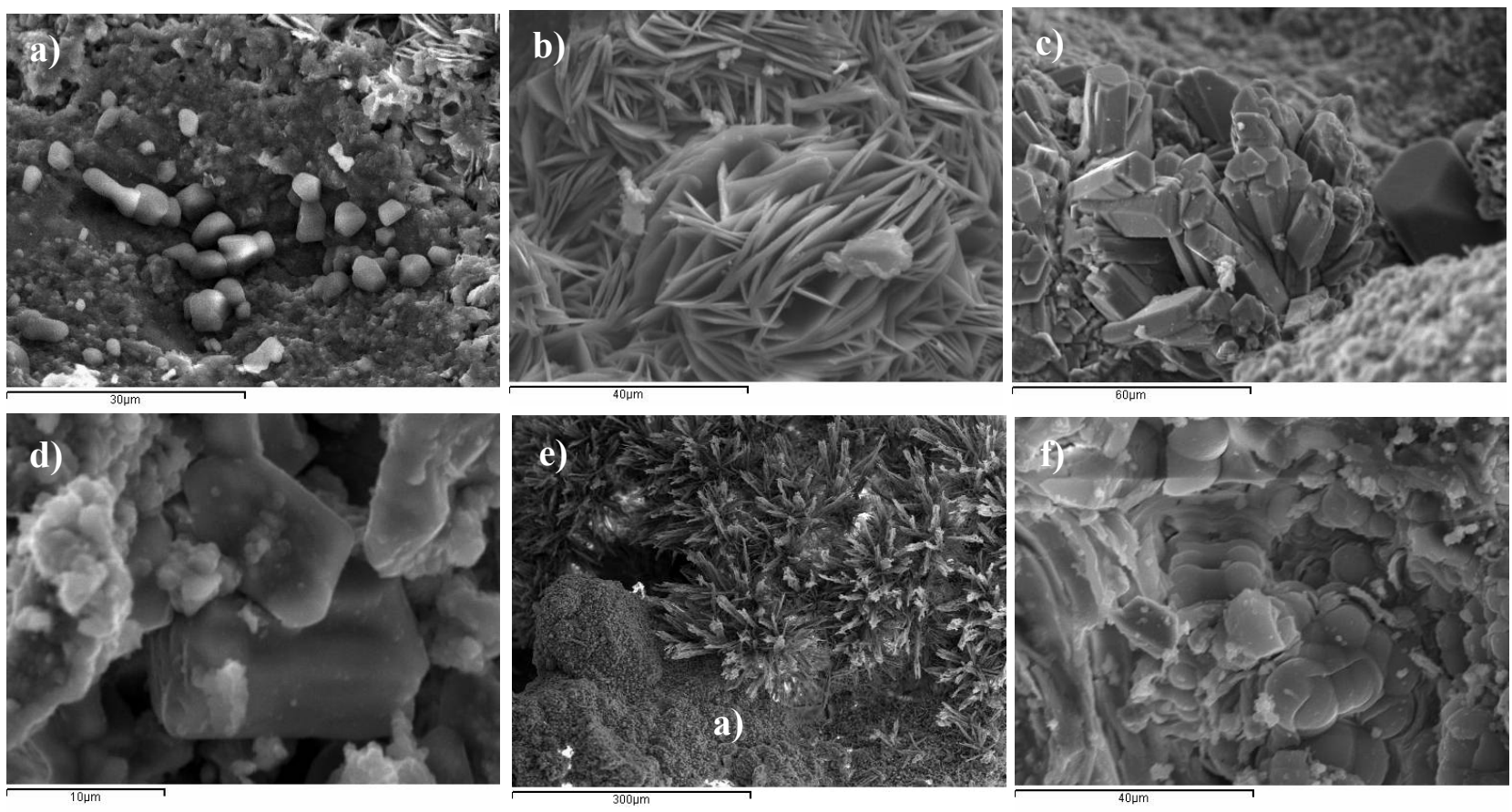

Figure 3. SEM micrographs showing a) halite crystals (Evora Cathedral) b) neoformation aragonite crystals (Mertola Mosque) c) neoformation brucite crystals (Evora Cathedral), d) neoformation gypsum crystals (Elvas Cathedral) and e) and f) pozzolanic neoformation calcium silicates (Mertola's River Tower and Elvas Cathedral, respectively).
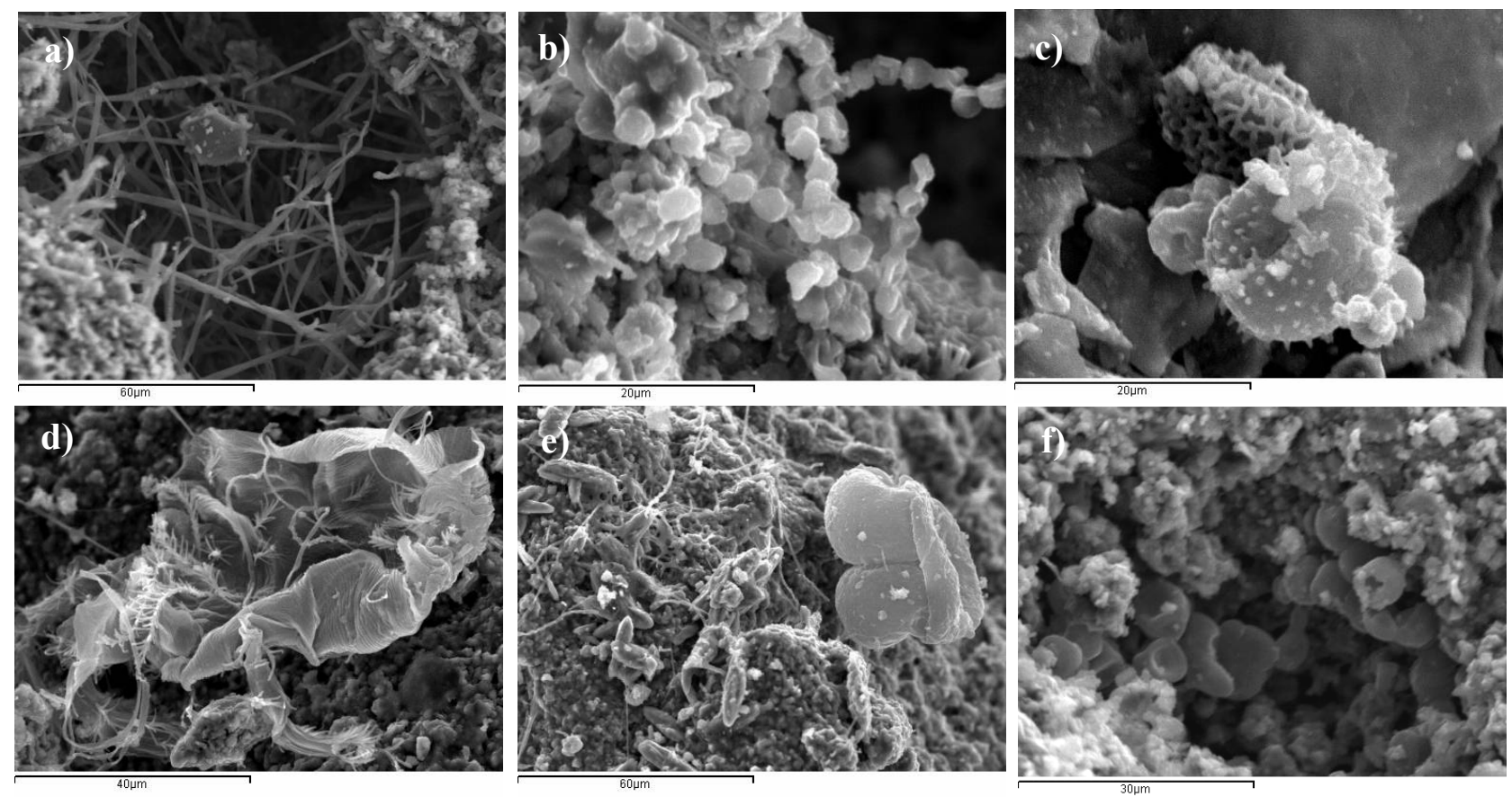

Figure 4. SEM micrographs of different biological materials from Evora Cathedral (a, b and c); Elvas Cathedral (d and e) and Mertola's River Tower (f). 